\title{
AMERICAN WOODCOCK BREEDING RANGE EXTENSION
}

ROBERT W. NERO, Wildlife Branch, Box 14, 1495 St. James Street, Winnipeg, Manitoba. R3H OW9

The status and breeding distribution of the American Woodcock in Manitoba has been previously reviewed in the Blue Jay. ${ }^{2}$ Woodcock have been shown to occur regularly as breeding residents south of Lake Winnipeg and east of the Red River, irregularly, west to within 80 $\mathrm{km}$ (50 mi.) of Winnipeg and north to within $136 \mathrm{~km}$ (85 mi.).

In recent years, woodcock have been observed several times in Riding Mountain National Park (RMNP). Field notes by Jacques Saquet, former Park Naturalist

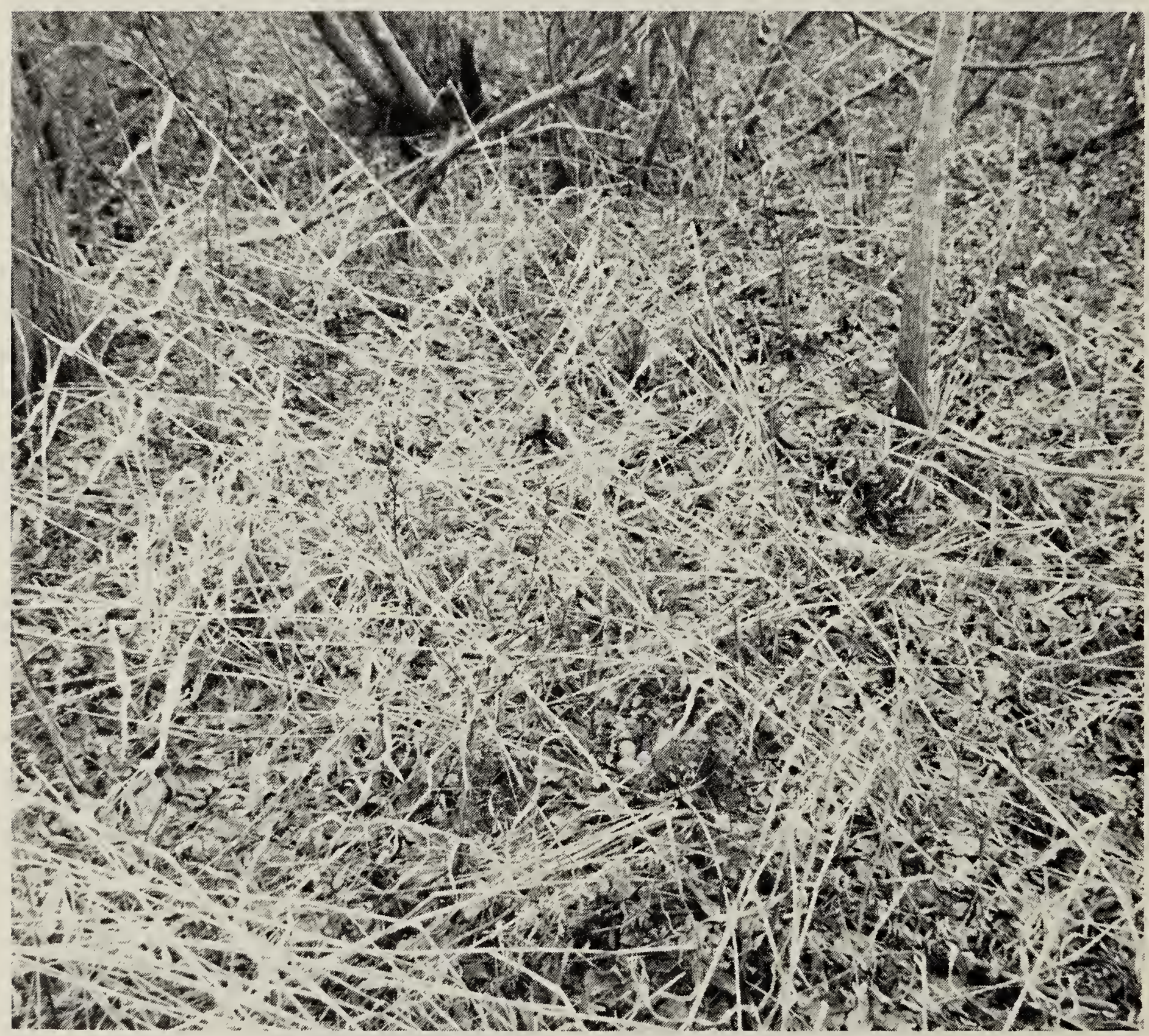

Riding Mountain (McCreary) nest site. Eggs visible lower center. 19 May 1983.

Ken L. Wainwright 
(now at Fort Smith, N.W.T.), contain the following records which have been abbreviated here: 23-24 April 1980, one calling and seen near Kinosoo Lake Trail; 28 April 1980 (with Celes Davar), one in same area, but not observed after that date; 31 May 1982, two heard by Diane Kunec and Cheryl Campbell (now C. Penny) on the Brule Trail; 1 June 1982, one on the Kinosoo Lake Trail at the same location as in 1980, and two others on the Brule Trail; 2 June 1980 (with Ray Whaley), three observed, one in extensive aerial display, on the Brule Trail; 3 June 1980, three males recorded - one near Brule Trail - Grey Owl parking lot, one near post 16 and another near post 15 on the Brule Trail. These records strongly suggested that the American Woodcock was breeding in RMNP, but there has been no direct evidence for this.

An abandoned woodcock nest with four fresh eggs found $1.6 \mathrm{~km}$ (1 mi.) east of the East Gate of RMNP, off P.R. 19 on 18 May 1983, proves that woodcock nest this far west. The nest, the third for Manitoba, was found by Ken L. Wainwright while he was searching for a legal surveys monument (pers. comm., December 1985). The nest, which was close to the monument, was $7.6 \mathrm{~m}$ (25 $\mathrm{ft}$.) from a grid road with a small brook beside it. The site, below the RMNP escarpment, is on fairly level, low ground and about $16 \mathrm{~km}$ (10 mi.) south of McCreary. The nest was apparently abandoned because of snow and cold. A snowstorm began in RMNP on 12 May 1983 with strong northwesterly winds and snow. The storm persisted until late on 13 May, leaving approximately $10 \mathrm{~cm}$ (4 in.) of snow on the ground. Park records show $7 \mathrm{~cm}$ of snow for 13 May, $1.6 \mathrm{~cm}$ for $14 \mathrm{May}$, and up to $4 \mathrm{~cm}$ for 15 May. The maximum daytime temperature at the North Gate of RMNP was $-7.5^{\circ} \mathrm{C}$; maximum daytime temperature at the South Gate on 14 May was - $5^{\circ} \mathrm{C}$ (pers. comm., Penny, December 1985; Saquet, January 1986).
Notes by Saquet (pers. corr., January 1986) show that the nest site was mostly low ground, with mainly Speckled Alder $\left(2-4^{\prime} \mathrm{dbh}\right)$, a few mature Manitoba Maples and Black Poplars in the vicinity. Other nearby vegetation included Ostrich Fern, grasses, Stinging Nettle, Chokecherry and Raspberry. The nest itself was within $4.8 \mathrm{~m}$ (16 ft.) of the brook and in a slight depression in dead grass (see photos).

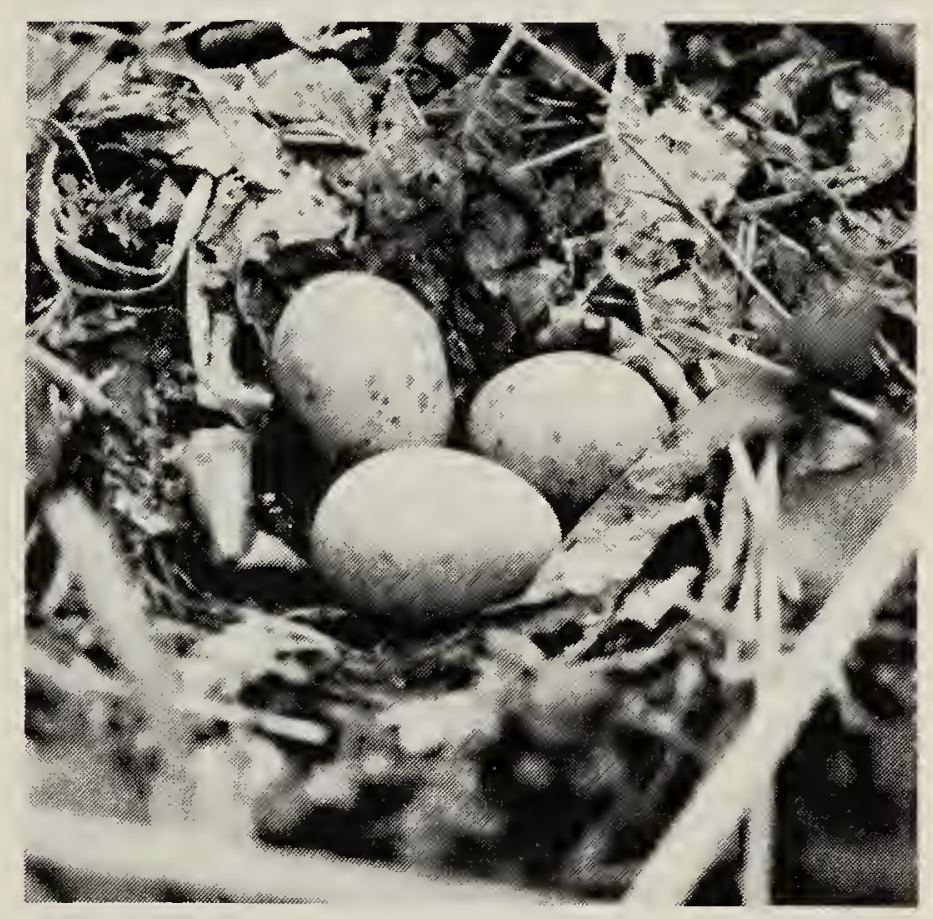

Close-up of nest; note the dead leaves blown into the nest.

\section{Ken L. Wainwright}

Claude Bonnefoy, then a Park Interpreter, visited the nest site with Wainwright on the day of its discovery (pers. comm., January 1986). Because no adult bird was seen, and being uncertain of the identification, one egg was taken to the Park Interpretation Centre. With the help of Celes Davar, it was identified as a woodcock egg. That egg, according to Bonnefoy, unfortunately was lost when someone opened the door and a gust of wind blew the egg off a table and onto the floor. The remaining three eggs were left in the nest in the hope that the nest might still be occupied. On a visit on 19 May, dead leaves in the nest (see photo) and an unbroken cobweb over the eggs convinced Bonnefoy that the nest had been deserted. Accordingly, the remain- 
ing three eggs were taken and delivered to Herb Copland, Assistant Curator of Birds, Manitoba Museum of Man and Nature. I examined the eggs (catalogue no. 1.21-375 (a-c)) in Herb's company in December 1985. Herb stated that the eggs, which he had prepared, had been fresh.

The 1983 nest record just outside the boundary of RMNP extends the known breeding range about $136 \mathrm{~km}$ (85 mi.) northwest of the previous most westerly nesting (Reaburn, hen with brood, 24 May 1975, E.F. Bossenmaier1), thus extending the known North American breeding range. It now seems likely that woodcock breed within RMNP, at least in some years. Moreover, this record lends support to earlier woodcock sightings in RMNP (one bird, 28 September 1933), Antler Creek, North Dakota (just south of the Manitoba Saskatchewan border, April 1923), and lends credence to reports prior to 1924 for Oxbow and Moose Mountain, Saskatchewan. ${ }^{1}$ It is even possible that woodcock may have bred at those localities at some time. Woodcock nests are notably difficult to find, but birds on territory make conspicuous and readily identifiable sounds. It remains to determine whether woodcock are regular residents over much of the range in which it is now known they can breed or in which they have occurred.

A fourth Manitoba woodcock nest record may be mentioned. Bill Koonz flushed a female from a nest near Bissett, Manitoba on 1 June 1984 (pers. comm., June 1984). This was on the Quesnel Lake road about $6.4 \mathrm{~km}$ (4 mi.) west of Bissett and within 91 m (100 yards) of P.R. 304. Three newly-hatched chicks left the nest and followed the hen. An addled egg that remained was collected, together with shell fragments of the other three eggs; all are in the collections of the Manitoba Museum of Man and Nature. The habitat at the nest site consisted of fairly open, young Trembling Aspen. In an earlier report, a female with five good-sized chicks was found $40 \mathrm{~km}$ (25 mi.) west of this site at Manigotogan. ${ }^{2}$ It may be worth mentioning as a phenological indication of when to look for woodcock nests, that Koonz found his nest accidentally while searching for morels.

\section{Acknowledgements}

I would like to thank Jacques Saquet for bringing the RMNP nest record to my attention and for allowing me to publish his data. Ken Wainwright went to considerable effort to unearth the photographs and also provided useful information. Additional information was generously supplied by Claude Bonnefoy, Herbert W.R. Copland, Celes Davar, William H. Koonz, Cheryl Penny, Jacques Saquet and Ray Whaley.

'NERO, R.W. 1977. The American Woodcock in Manitoba. Blue Jay 35:240- 256.

2 NERO, R.W. 1981. Additional American Woodcock notes for Manitoba. Blue Jay 39:202-205. 